\title{
Effect of particulate organic carbon on heterotrophic bacterial populations and nitrification efficiency in biological filters
}

\author{
L. Michaud ${ }^{\mathrm{a}}$, J.P. Blancheton ${ }^{\mathrm{b}^{\star}}$, V. Bruni ${ }^{\mathrm{a}}$ and R. Piedrahita ${ }^{\mathrm{c}}$ \\ aUniversity of Messina, Department of Animal Biology and Marine Ecology, Salita Sperone, 31-98166 Messina, \\ Italy \\ bIFREMER-Palavas, Chemin de Maguelone, 34250 Palavas-les-flots, France \\ 'University of California, Department of Biological and Agricultural Engineering, Davis, CA 95616, USA \\ *: Corresponding author : Tel.: +33 4675041 12; fax: +33 4676828 85. jean.paul.blancheton@ifremer.fr
}

\begin{abstract}
Competition between heterotrophic and nitrifying bacteria is of major practical importance in aquaculture biofilter design and operation. This competition must be understood to minimize the negative impact of heterotrophic bacteria on an aquaculture system. On the other hand, the heterotrophic population is suspected of having a positive effect against pathogenic bacteria. Little information is available on the bacterial communities present within aquaculture systems, except for nitrifying bacteria, but a combination of traditional aquacultural engineering research methods and novel microbiological techniques offers new opportunities for the study of these communities.

The heterotrophic bacterial population activity and the nitrification efficiency of a submerged biological filter were studied for an influent TAN concentration of $2 \mathrm{mg} / \mathrm{l}$ and varying $\mathrm{C} / \mathrm{N}$ ratios. The TAN removal rate was found to be $30 \%$ lower at a $\mathrm{C} / \mathrm{N}$ ratio of 0.5 than at a $\mathrm{C} / \mathrm{N}$ ratio of 0 . For higher $\mathrm{C} / \mathrm{N}$ ratios the reduction in nitrification efficiency was $50 \%$ while the attached bacterial abundance was doubled. Moreover, results confirm that abundance of sheared and attached bacteria are correlated. It is not known to what extent biofilter configuration might influence the relationship between heterotrophic and nitrifying bacteria, and further work will be carried out with moving bed and fluidized filters. A better understanding of the role of the heterotrophic bacteria in RAS will help to optimize any positive "biocontrol" effect and to minimize the microbial degradation of rearing water and the reduction of nitrification rates.
\end{abstract}

Keywords: Nitrification; Heterotrophic bacteria; Particulate organic matter; Recirculating aquaculture system 


\section{Introduction}

In an environment like an on-shore Recirculating Aquaculture System (RAS), the importance of bacterial communities is of the same order of magnitude as fish in terms of processes directly linked to their activities and their effect on water quality. Usually in a RAS, autotrophic nitrifying bacteria (AB) remove ammonia at a sufficient rate to maintain water quality at a level adequate to prevent ammonia toxicity to the fish (Zhu and Chen, 1999). Heterotrophic bacteria (HB) constitute an important factor in terms of oxygen consumption, metabolic by-products they release after cellular lysis, the diseases they may cause in fish and, finally, for the competition they may have with autotrophic bacteria for oxygen and space (Léonard et al., 2002; Nogueira et al., 2002).

The organic carbon/inorganic nitrogen $(\mathrm{C} / \mathrm{N})$ ratio in the water links the availability and competition for organic carbon and ammonia. For a high $\mathrm{C} / \mathrm{N}$ ratio, heterotrophic bacteria outcompete nitrifiers for available oxygen and space in biofilter media. It is only when the $\mathrm{C} / \mathrm{N}$ ratio is relatively low that NB are able to outcompete $\mathrm{HB}$. However the critical $\mathrm{C} / \mathrm{N}$ ratio affecting the nitrification rate varies among systems and is related to the characteristics of the organic carbon available.

Because nitrification is a key water treatment process in a RAS, nitrifying bacteria and TAN removal rates have been studied in some detail (Tal et al., 2003). On the contrary, less attention has been paid to the non-pathogenic heterotrophic bacteria (Léonard et al., 2000; 2002). In previous studies Léonard and colleagues $(2000 ; 2002)$ demonstrated that the biological filter is the main source of HB in a RAS, that the dissolved organic carbon in a RAS is constituted mainly by humic substances, and that particulate organic carbon trapped in the biological filter is the main source of carbon available for heterotrophic growth.

Achieving a better understanding of the biology and ecology of the microbial populations in a biological filter is needed for the development and optimisation of efficient and economic RAS in general. The aim of this work was to evaluate the effect of particulate organic matter on the heterotrophic bacterial communities of a pilot scale submerged biological filter and consequently on nitrification efficiency.

\section{Materials and Methods}

\subsection{Experimental facilities and procedures}

Four identical pilot scale biological filters filled with a pre-colonized packing media (Biogrog) were used (Table 1). The filters functioned in parallel and received the same influent water quality, constituted from heated $\left(20^{\circ} \mathrm{C} \pm 1\right)$, sand-filtered, and UV disinfected seawater. The $\mathrm{pH}$ remained between 7.5 and 8 .

Table 1: Characteristics of the pilot scale submerged biofilters. The water retention time and water velocity are calculated ignoring the volume displaced by the packing media.

\begin{tabular}{ll}
\hline Diameter & $11 \mathrm{~cm}$ \\
Cross-sectional area & $95 \mathrm{~cm}^{2}$ \\
Height & $85 \mathrm{~cm}$ \\
Volume & $8075 \mathrm{~cm}^{3}$ \\
Flow rate & $0.121 \mathrm{~m}^{3 / \mathrm{h}}$ \\
Water retention time & $4.03 \mathrm{~min}$. \\
Water velocity & $12.74 \mathrm{~m} / \mathrm{h}$ \\
\hline
\end{tabular}


Particulate organic matter (POM) containing on average $175 \mathrm{mg}$ of organic carbon per gram of dry matter (Franco-Nava, 2003) and ammonia (ammonium chloride) were continuously added at the inlet of each filter with a peristaltic pump. The input of ammonia was set to achieve a TAN concentration of $2 \mathrm{mg} / \mathrm{l}$.

Filters were operated with continuous feeding for at least four weeks to allow the formation of a steady-state biofilm before starting the experiment. Inputs of POM were calculated to obtain $\mathrm{C} / \mathrm{N}$ ratios of $0,0.5,1$ and 2. Each enrichment step was run during three weeks and was performed in duplicate. At the end of each step, the filters were washed and left running during one week only with seawater and ammonia. During the final two weeks of each $\mathrm{C} / \mathrm{N}$ step, samples were collected for chemical, physical, and microbiological analyses.

\subsection{Particulate organic matter source}

The POM used in the experiment was collected from particle separators at the outlet of a seabass rearing tank in a RAS. The POM was constituted mainly by fecal pellets and by non-ingested feed. After collection, the POM was concentrated by centrifugation $(10,000 \mathrm{rpm})$, sterilized by autoclaving $\left(121^{\circ} \mathrm{C}, 1 \mathrm{~atm}\right.$ for $\left.20 \mathrm{~min}\right)$ and freeze-dried. Finally it was ground and sieved on a $50 \mu \mathrm{m}$ screen to obtain a uniform powder that was easy to inject into the filters.

\subsection{Microbiological analysis}

\subsubsection{Sampling procedures}

Attached HB were sampled from four pieces of packing media at each sampling point. Pieces were collected in a sterile beaker, weighed and pre-incubated at $4^{\circ} \mathrm{C}$ for $10 \mathrm{~min}$ in $100 \mathrm{ml}$ of sterile detachment buffer $(0.1 \%$ of sodium pyrphosphate in a phosphate buffer saline: $130 \mathrm{mM} \mathrm{NaCl}$, $10 \mathrm{mM} \mathrm{Na}_{2} \mathrm{HPO}_{4}$, and $10 \mathrm{mM} \mathrm{NaH} \mathrm{PO}_{4}$ at a $\mathrm{pH}$ of 7.4). Following the pre-incubation, packing media pieces were scraped with a sterile iron brush mounted on a mini-drill, until all the surface appeared clean. Finally, samples received an ultrasonic treatment (10min at $20 \mathrm{kHz}$, in an ice bath). An aliquot of this mixture was collected and used for microbiological analysis.

Free-living HB were sampled by using sterile bottles. An aliquot was diluted in the detachment buffer and a soft ultrasonic treatment was performed in order to detach bacteria associated to particles (Mermillod-Blondin et al., 2001).

\subsubsection{CFU (Colony Forming Units)}

Counts of cultivable heterotrophic free living and attached bacteria were performed by the spread plate method on Marine Agar (Difco 2216) sterilized by autoclaving ( $121^{\circ} \mathrm{C}$, $1 \mathrm{~atm}$ for $20 \mathrm{~min}$ ). Dilutions were performed in $34 \mathrm{~g}^{-1}$ sterile sodium chloride solution. Plates were set up in duplicate for each dilution. Only plates having between 20 and 200 colonies were considered. Incubation time was 10 days at $25^{\circ} \mathrm{C}$. Bacterial concentrations were expressed as CFU per $\mathrm{ml}$ for free living bacteria and as CFU per gram of wet packing for attached ones, (Leonard et al, 2000) because the surface area of the packing material was not well defined.

The presence of presumptive vibrios (PV), usually found in the marine environment, was evaluated by plating a subsample on TCBS (thiosulphate, citrate, bile and sucrose) agar plate (Difco). Incubation was performed at $20^{\circ} \mathrm{C}$ for 10 days. 


\subsubsection{Direct microscopic enumeration}

Samples for direct enumeration of free living bacteria were fixed in 3.7\% (wt/vol) formalin and stored at $-20^{\circ} \mathrm{C}$ until processing. For free bacteria a sample aliquot was filtered directly on a $25 \mathrm{~mm}$ diameter, $0.2 \mu \mathrm{m}$ pore size black polycarbonate filter, under a vacuum of $<5 \mathrm{~mm} \mathrm{Hg}$ and stained with DAPI (4',6- diamidino-2-phenilindole) (Porter and Feig, 1980). Cells were visualized by epifluorescence microscope. For attached bacteria and in order to overcome excessive interference with particles, formalin-fixed samples were diluted 50 fold with sterile phosphate buffer saline (130mM NaCl, $10 \mathrm{mM} \mathrm{Na}_{2} \mathrm{HPO}_{4}$ and $\left.10 \mathrm{mM} \mathrm{NaH}_{2} \mathrm{PO}_{4}, \mathrm{pH} 7.4\right)$. Then Tween $80(0,1 \% \mathrm{vol} / \mathrm{vol})$ was added to the diluted samples which were incubated $15 \mathrm{~min}$ at room temperature. Finally, the samples were pre-filtered on $3 \mu \mathrm{m}$ membranes and prepared as described previously for free bacteria.

\subsection{Chemical analysis.}

Physical and chemical analyses were performed according to current protocols and to in-house methods. Ammonia, nitrite and nitrate were analyzed with a Technicon ${ }^{\circledR}$ Autoanalyser II as described by Treguer and La Corre (1974).

The nitrification performance was expressed as volumetric TAN removal rate and calculated with the following expression:

TAN removal rate $=\left([T A N]_{\text {in }}-[\text { TAN }]_{\text {out }}\right) \times \mathrm{Q} / \mathrm{V}$

where $[\mathrm{TAN}]_{\text {in }}$ and $[\mathrm{TAN}]_{\text {out }}$ are the TAN concentration at the inflow and at the outflow of the filter respectively $\left(\mathrm{g} \mathrm{m}^{-3}\right)$, Q is the water flow rate $\left(\mathrm{m}^{3}\right.$ day $)$ and $\mathrm{V}$ is the volume of packing media of the

biofilter $\left(\mathrm{m}^{3}\right)$. Similar calculations were made for nitrate production and oxygen consumption rates. Each nitrification parameter was expressed as a percentage of the maximum value found.

DOC was analyzed with a Shimadzu TOC5000 analyzer, and suspended solids (SS) were determined by filtering a known volume of water on a pre-weighed and pre-combusted $\left(450^{\circ} \mathrm{C}\right.$ for 30min) glass fiber filter (Whatman GF/C, Springfield Mill, UK). After filtration, the filters were dried at $65^{\circ} \mathrm{C}$ for two days and weighed again.

\subsection{Statistical analysis.}

Results were analyzed using analysis of variance (ANOVA). Comparison between groups for a significant difference of mean or rank values were performed after normality and variance tests. Statistical calculations were performed with SigmaStat software for Windows, version 2.0 (Copyright 1992-1995 Jandel Corporation)

\section{Results and discussion}

The TAN removal rate was maximal in the biofilter enriched with nitrogen only $(\mathrm{C} / \mathrm{N}=0)$. Nitrification efficiency was strongly impacted by the addition of POM (Figure 1). The TAN removal rate was significantly lower at $\mathrm{C} / \mathrm{N} \geq 0.5$ than at $\mathrm{C} / \mathrm{N}=0(\mathrm{P}=0.006)$.

From $\mathrm{C} / \mathrm{N}=1$ to $\mathrm{C} / \mathrm{N}=2$ the loss of nitrification efficiency $(7 \%)$ was less significant than from $\mathrm{C} / \mathrm{N}=0$ to $\mathrm{C} / \mathrm{N}=1(45 \%)$, suggesting that the impact of POM on nitrification became less and less important as the carbon concentration increased (Zhu and Chen 2001). The nitrate production rate decreased by $24 \%$ for $\mathrm{C} / \mathrm{N}=0.5,56 \%$ for $\mathrm{C} / \mathrm{N}=1$ and $73 \%$ for $\mathrm{C} / \mathrm{N}=2$, all compared to $\mathrm{C} / \mathrm{N}=0$. In this case the inhibitory effect of POM remained comparable for the various $\mathrm{C} / \mathrm{N}$ ratios tested. The concentration of nitrite was always very low (data not shown). 
Figure 1: Nitrification performance indicators expressed as a percentage of the maximum.

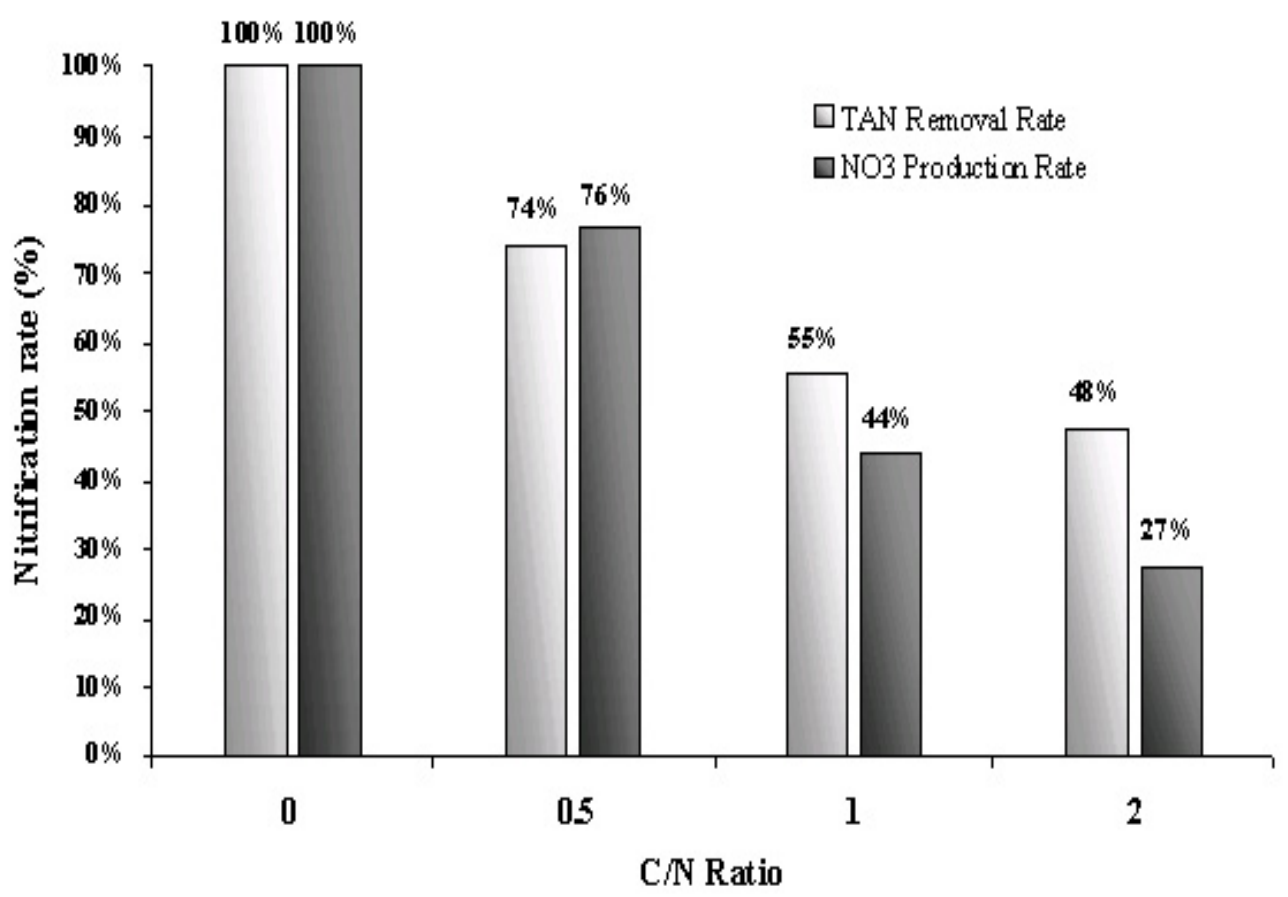

The easily biodegradable organic carbon enrichment supporting the heterotrophic activity resulted in the establishment of a competition between chemoautotrophic nitrifiers and heterotrophs for oxygen, nutrients and space inside the multispecific biofilms causing a reduction of nitrification rates. This competition between the different microbial groups can result in a spatial distribution of microorganisms within the biofilm matrix that affects mass transfer processes and thus the performance of nitrification (Fdz-Polanco et al.,2000). Okabe et al. (1996) showed that hetrotrophs and nitrifiers coexisted in the outermost biofilm for $\mathrm{C} / \mathrm{N}=0$. At $\mathrm{C} / \mathrm{N}=1.5$ heterotrophs dominated in the outermost biofilm and nitrifiers were present only in the deeper biofilm. Finally, a further increase of the $\mathrm{C} / \mathrm{N}$ ratio resulted in a stronger stratification of microbial species and in an inhibition of nitrification.

In addition to the competition mechanisms, nitrification efficiency can be directly inhibited by organic matter. The direct inhibition of nitrifying bacteria by specific forms of organic carbon is called allelopathy. In this case compounds having a structural homology with ammonia can create an interference with the active site of ammonia monoxygenase and metal-binding compounds can reduce the availability of copper, therefore inactivating enzymes involved in the nitrification process (Bedard and Knowles, 1989).

A loss of nitrogen was observed when comparing the total dissolved inorganic nitrogen concentration at the inlet of the filters $\left(\mathrm{DIN}_{\text {in }}\right)$ and the DIN at the outlet $\left(\mathrm{DIN}_{\text {out }}\right)$ (Fig. 2). It is well known that heterotrophic bacteria can efficiently use ammonia if an appropriate source of carbon is available, and that the difference in energetic costs of using ammonia instead of proteins as a nitrogen source is very low (Russel and Cook, 1995). Although the heterotrophic ammonium uptake can be significant in various environments (Kirchman, 1994), the total bacterial biomass production in the filters, evaluated by direct microscopic enumeration (Fig. 3 and 4), didn't appear sufficient to ascribe the unbalance in the DIN concentration only to a heterotrophic nitrogen uptake. Another possible explanation for this difference could be a dissimilatory utilization of dissolved nitrogen compounds by denitrification microorganisms. In biolfilters filled with a microporous mineral packing media, hypoxic or totally anoxic micro-niches are certainly present and they were probably enhanced by the POM used for the $\mathrm{C} / \mathrm{N}$ enrichment. In this kind of environment, anaerobic 
denitrification could play an important role as bacteria (belonging to the most common genera like Vibrio, Pseudomonas, Acinetobacter Flavobacterium-Bacterioides-Cytophaga group, etc.) that can reduce nitrate and nitrite to molecular nitrogen are present in all water habitats. Moreover a novel form of anaerobic ammonia oxidation (anammox) bacteria (Strouss et al., 1997; 1999) can contribute to ammonia removal, but their presence inside biofilters has not been examined to date (Tal et al., 2003).

Figure 2: Difference between inlet and outlet concentrations of dissolved inorganic nitrogen (DIN) for the various C/N ratios. The error bars represent the standard deviations.

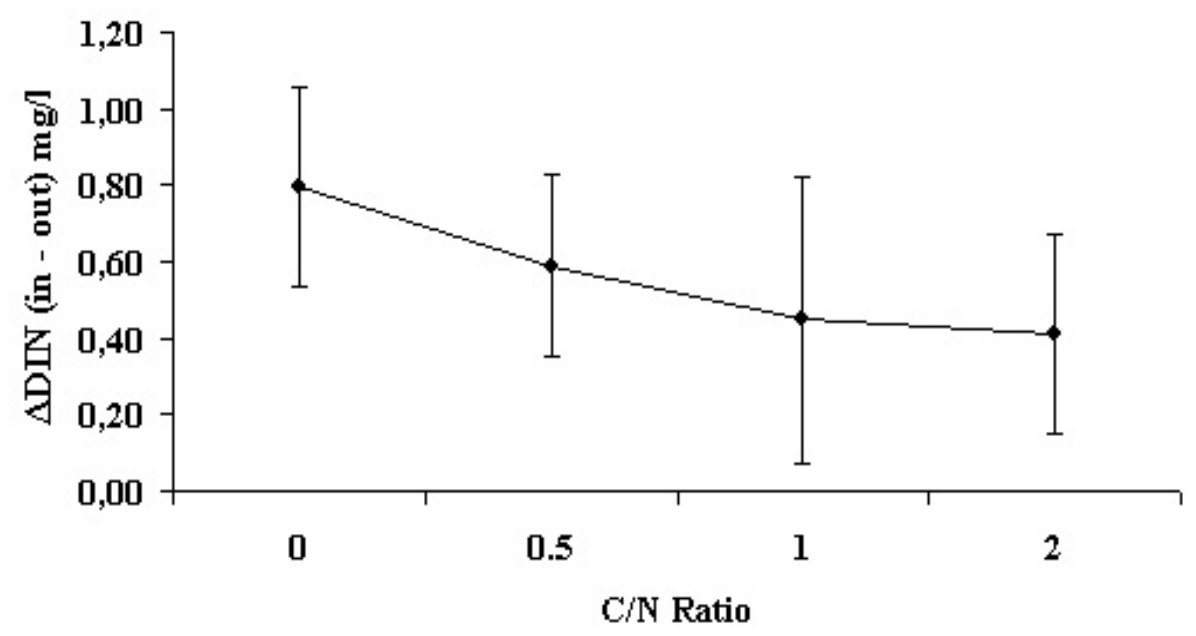

Figure 3: Total number of bacterial cells (Cells/g) and cultivable heterotrophic bacteria (CFU/g) attached to the packing media.

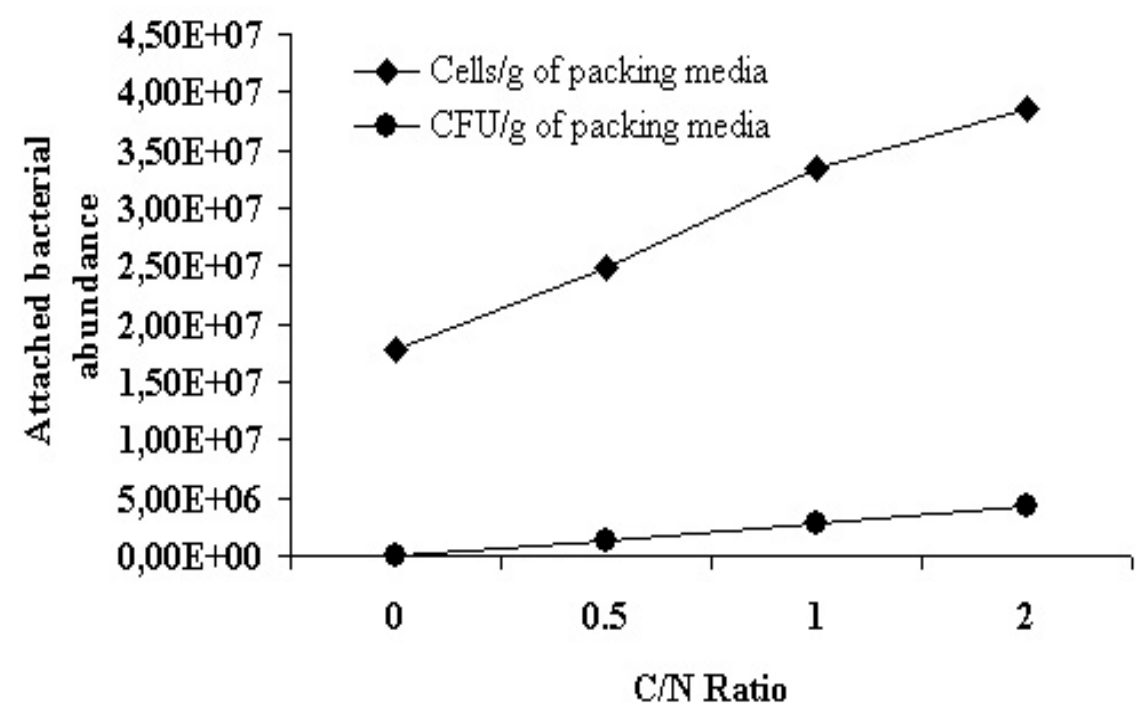


Figure 4: Total number of bacteria (Cells/g) and cultivable heterotrophic bacteria (CFU/g) found in the biofilter effluent.

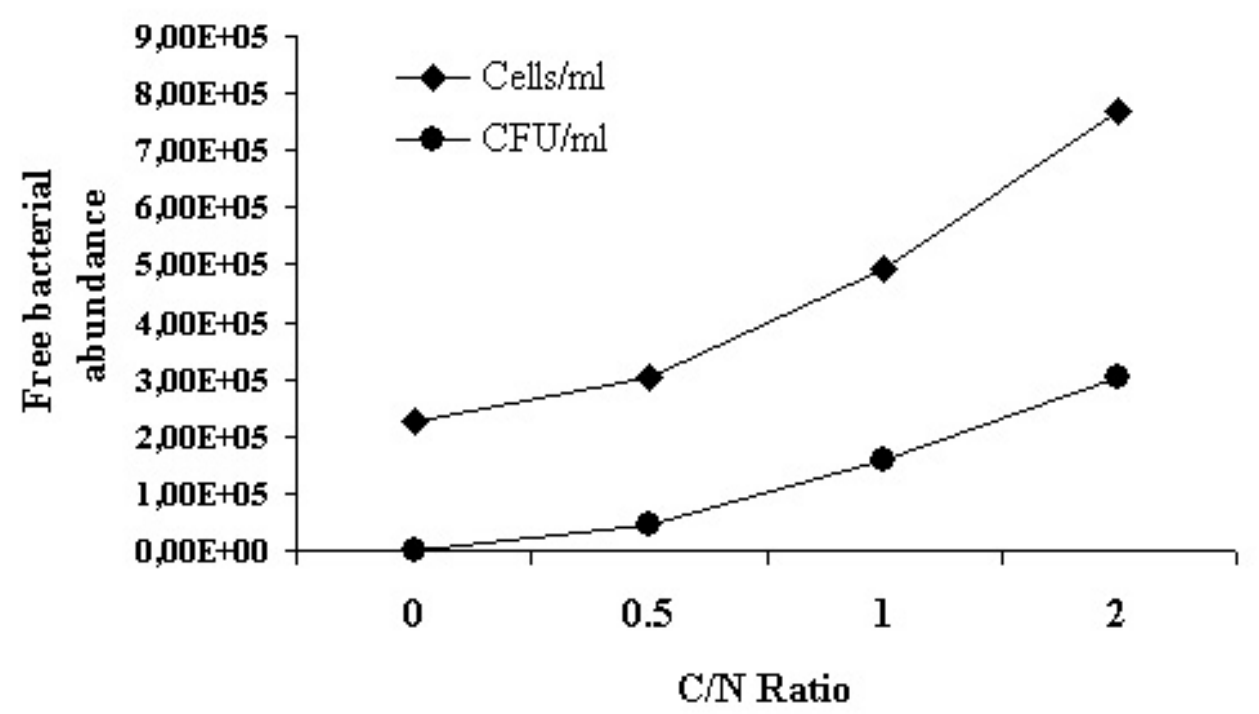

There was a linear correlation between the influent concentration of SS and the SS production (OutIn) in filters (Fig. 5). With the exception of very low influent SS concentrations, where the biofilters seemed to play a mechanical separation role, the production of SS increased with increasing influent SS concentration. The correlation between influent SS and the total bacterial production (Out-In) of filters is also shown in Fig. 5. It appears that a large proportion of the SS released from the filters is constituted by bacterial biomass produced from the influent POM.

There was a good correlation between the concentration of POC and heterotrophic bacteria abundance, both for attached and free-living bacteria (Fig. 3 and 4). Fig. 3 shows the abundance of bacteria attached on the mineral packing media. Results are expressed as colony forming units per gram of packing media (CFU/g) and cells per gram of packing media (Cells/g) for the heterotrophic cultivable bacteria (HCB) and for the total bacterial abundance, respectively. The number of HCB increased from $5.0 \times 10^{4} \pm 2.0 \times 10^{4}(\mathrm{M} \pm \mathrm{SD}) \mathrm{CFU} / \mathrm{g}$ for $\mathrm{C} / \mathrm{N}=0$ to $1.4 \times 10^{6} \pm 0.6 \times 10^{6}, 2.7 \times 10^{6} \pm$ $1.3 \times 10^{5}$ and $4.4 \times 10^{6} \pm 1.6 \times 10^{6}$ for $\mathrm{C} / \mathrm{N}=0.5,1$, and 2 , respectively. As expected, total bacteria counts were higher than cultivable bacteria: in this case $1.8 \times 10^{7} \pm 9.3 \times 10^{5}$ Cells/g were found for $\mathrm{C} / \mathrm{N}=0,2.5 \times 10^{7} \pm 1.3 \times 10^{6}$ for $\mathrm{C} / \mathrm{N}=0.5,3.4 \times 10^{7} \pm 7.7 \times 10^{5}$ for $\mathrm{C} / \mathrm{N}=1$, and $3.9 \times 10^{7} \pm 1.0 \times 10^{6}$ for $\mathrm{C} / \mathrm{N}=2$. 
Figure 5: Suspended solids production (Out - In) and total number of bacteria added to the water as it flowed through the biofilters (Out - In) as functions of influent suspended solids concentrations.
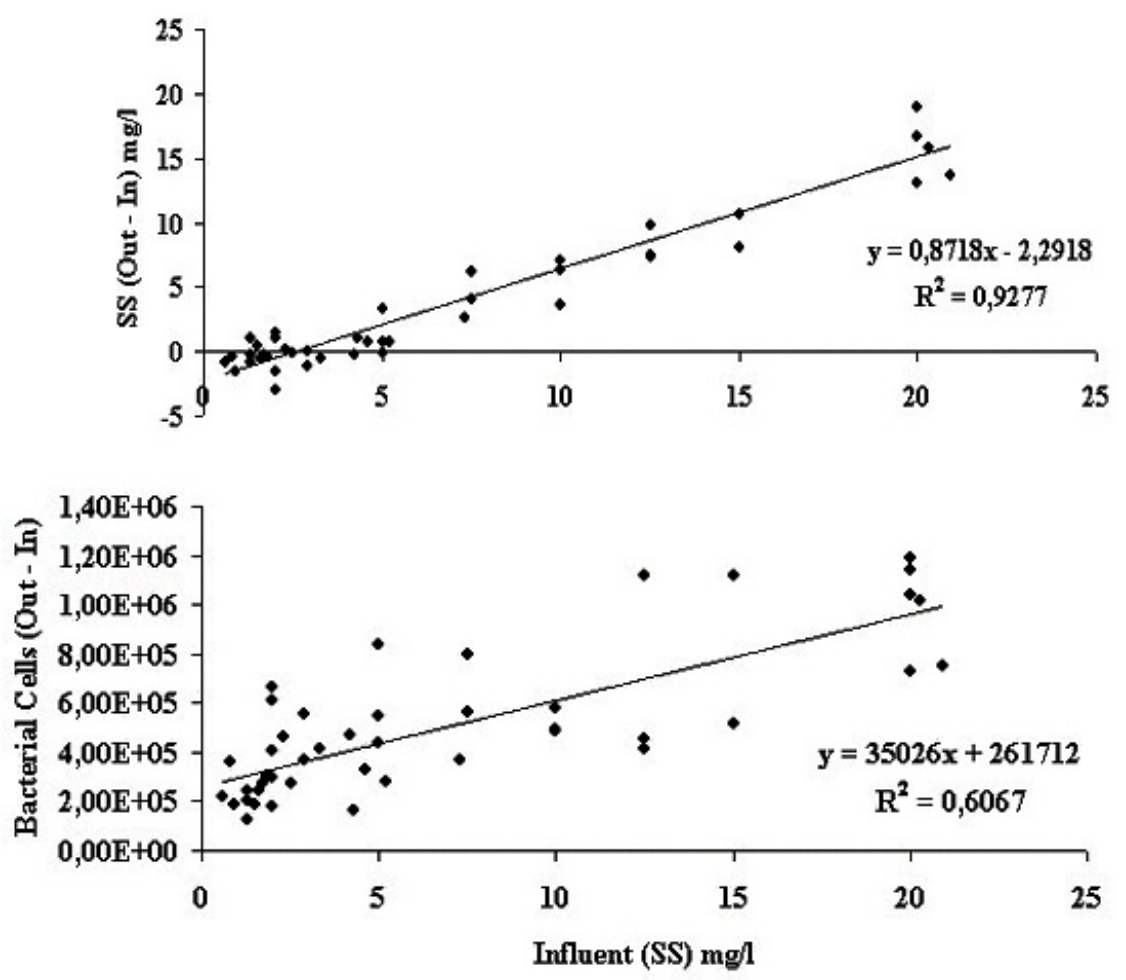

Figure 6: Relationship between the number of bacterial cells attached to the packing media and those present in the biofilter effluent.

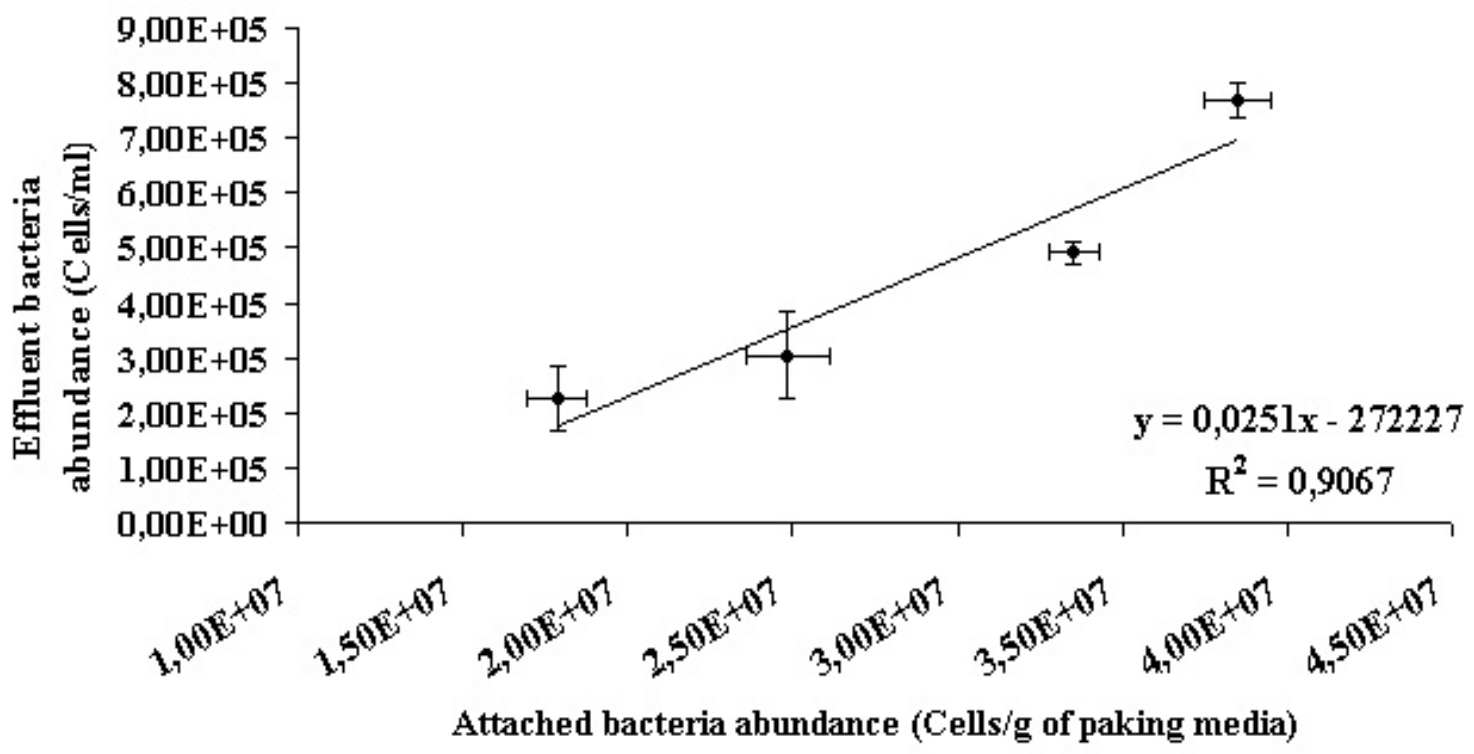


In this study the number of CFU was comparable with results obtained by Léonard et al. (2000) who found $7.3 \times 10^{6} \mathrm{CFU} / \mathrm{g}$, for an average $\mathrm{C} / \mathrm{N}$ ratio of 0.8 in rearing water (Franco-Nava, 2003). The concentration of free heterotrophic bacteria entering the biofilter was low $\left(1.6 \times 10^{2} \pm 1.0 \times 10^{2}\right.$ $\mathrm{CFU} / \mathrm{ml}$ ) and the total bacterial count was $5.0 \times 10^{3} \pm 1.6 \times 10^{3}$ cells $/ \mathrm{ml}$. Free living bacteria in the biofilter effluent increased with $\mathrm{C} / \mathrm{N}$ ratio from $4.9 \times 10^{2} \pm 1 \times 10^{2} \mathrm{CFU} / \mathrm{ml}$ for $\mathrm{C} / \mathrm{N}=0$ to $3.0 \times 10^{5} \pm$ $1.3 \times 10^{5} \mathrm{CFU} / \mathrm{ml}$ for $\mathrm{C} / \mathrm{N}=2$ (Fig. 4). The total bacterial abundance also increased from $2.3 \times 10^{5} \pm$ $0.6 \times 10^{5}$ cells $/ \mathrm{ml}$ for $\mathrm{C} / \mathrm{N}=0$ to $7.7 \times 10^{5} \pm 0.3 \times 10^{5}$ cells $/ \mathrm{ml}$ for $\mathrm{C} / \mathrm{N}=2$ (Fig. 4). As shown in Figure 6 there is a linear correlation between total bacterial cells attached to the packing media and free living bacteria in the biofilter effluent. This relationship confirmed the results obtained by Lèonard et al. (2000) who found the same correlation for cultivable heterotrophic bacteria.

The production of bacteria in the biofilters increased with increasing $\mathrm{C} / \mathrm{N}$ ratio, but the rise was more dramatic for cultivable bacteria than for total bacterial counts (Fig. 7). The ratio of cultivable bacteria increased from $0.2 \%$ for $\mathrm{C} / \mathrm{N}=0$ (both for attached and free bacteria) to $11 \%$ and $40 \%$ for $\mathrm{C} / \mathrm{N}=2$ for attached and free bacteria, respectively (Fig. 8). The increase of the cultivability ratio with increasing $\mathrm{C} / \mathrm{N}$ ratio could be due to a shift toward a selected bacterial population particularly adapted to the kind of substrate used, or to bacterial activation by the presence of POM.

Although the high quantity of organic matter may mask many cells during epifluorescence enumeration, the difference between cultivable heterotrophic bacteria and total bacterial abundance was high. It is possible that autotrophic cells were also included in the total counts, which would inflate the ratio of cultivable to total concentrations. No clear evidence was found in the literature to be able to evaluate the percentage of nitrifiers inside the kind of multispecific biofilms found in the biofilters tested.

Only a few cultivable PV were found in the influent water (less than 20 per $\mathrm{ml}$ ). The results obtained for the PV found in the biofilter effluent and for those attached are shown in Fig 9. The number of $\mathrm{PV}$ in the effluent increased with $\mathrm{C} / \mathrm{N}$ ratio, and there was a large increase at the highest $\mathrm{C} / \mathrm{N}$ ratio. As previously mentioned, members of this bacterial group have the dissimilative pathway for nitrate. However, most of them are potentially harmful to fish and it is desirable to keep their numbers low to reduce risks linked to their proliferation. It appears that preventing a rise in the $\mathrm{C} / \mathrm{N}$ ratio could be an effective way to limit their numbers.

Samples were collected during the experiment and stored to further perform FISH (Fluorescent in Situ Hybridization) analyses to evaluate the ratio of heterotrophic and autotrophic bacteria at each $\mathrm{C} / \mathrm{N}$ ratio. Furthermore, a large number of bacteria strains were isolated from the biological filter and will be used in future work to examine their pathogenicity or probiotic potential. However, it is also generally accepted that most microbial populations can contribute to maintaining a stable rearing environment (shelter effect), probably by releasing chemical substrates that have a bactericidal or bacteriostatic effect on other microorganisms or outcompeting them for chemical and available energy (Verschuere et al., 2000). 
Figure 7: Production of bacteria (Out - In) in the biofilters at different $\mathrm{C} / \mathrm{N}$ ratios, expressed as total number of bacteria $(\mathrm{Cells} / \mathrm{ml})$ and cultivable heterotrophic bacteria $(\mathrm{CFU} / \mathrm{ml})$.

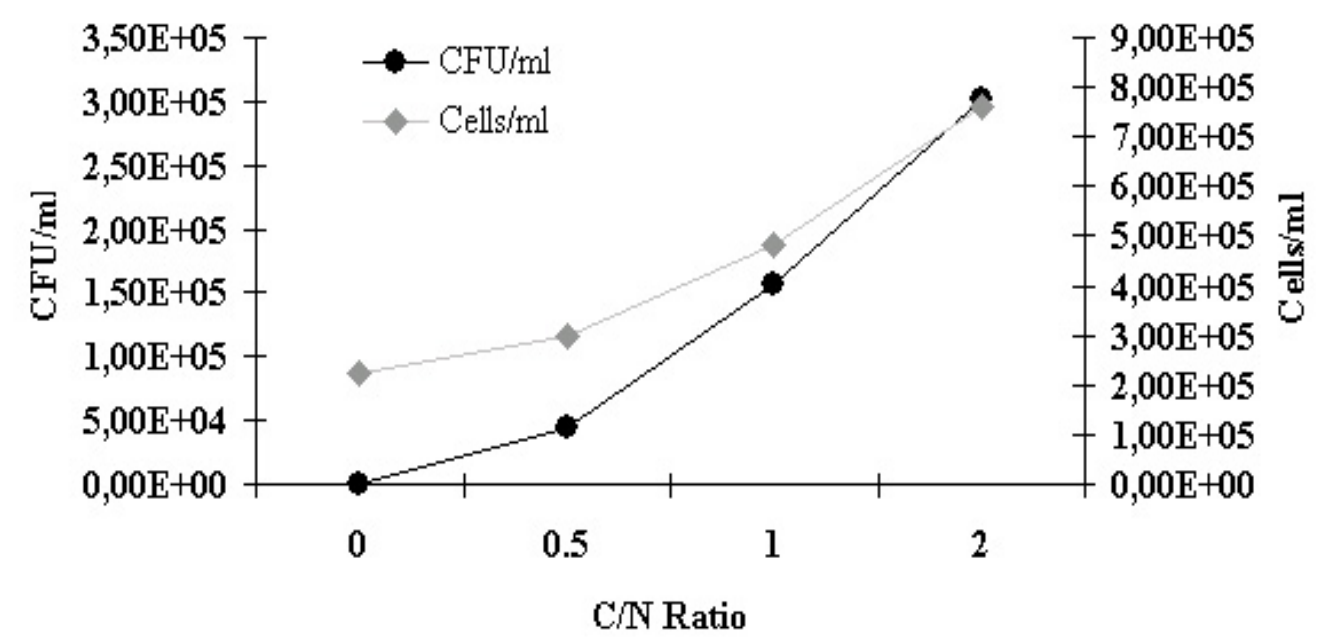

Figure 8: Percentage of the total number of bacteria (Cells/g of packing media or Cells $/ \mathrm{ml}$ ) that are cultivable (CFU/g or $\mathrm{CFU} / \mathrm{ml}$ ) for the attached and "free" (present in the biofilter effluent) bacteria.

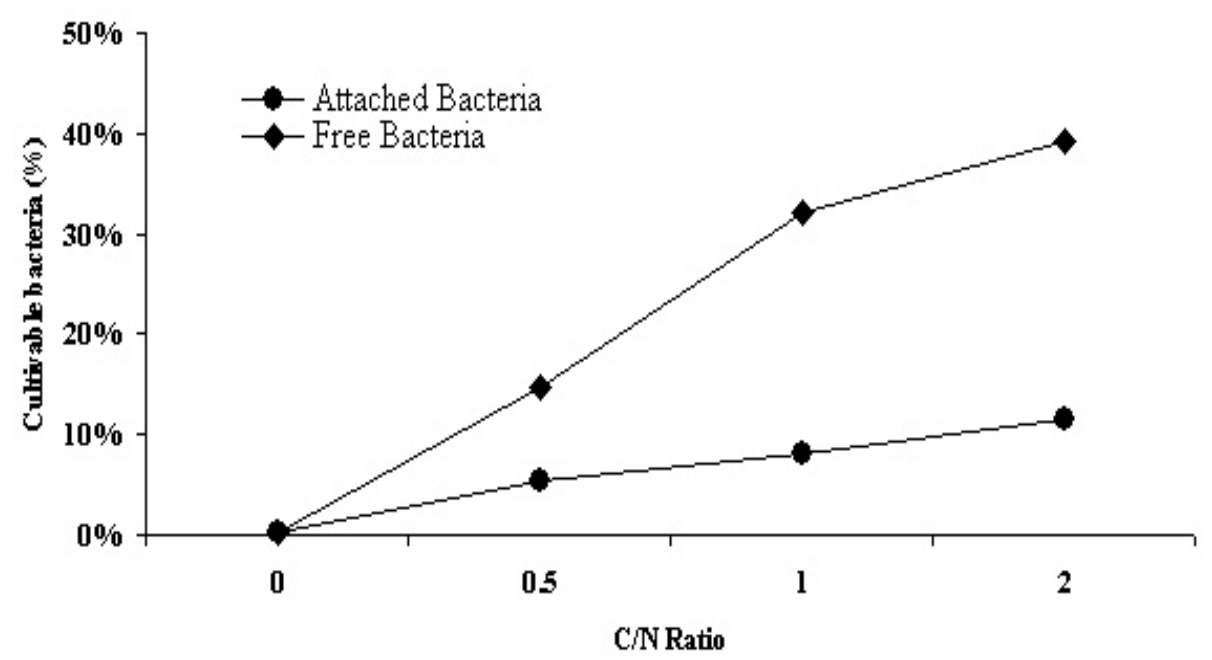


Figure 9: Presumptive vibrios (PV) bacteria present in the biofilter effluent (CFU/ml) and attached to the biofilter media $(\mathrm{CFU} / \mathrm{g})$ at different $\mathrm{C} / \mathrm{N}$ ratios.

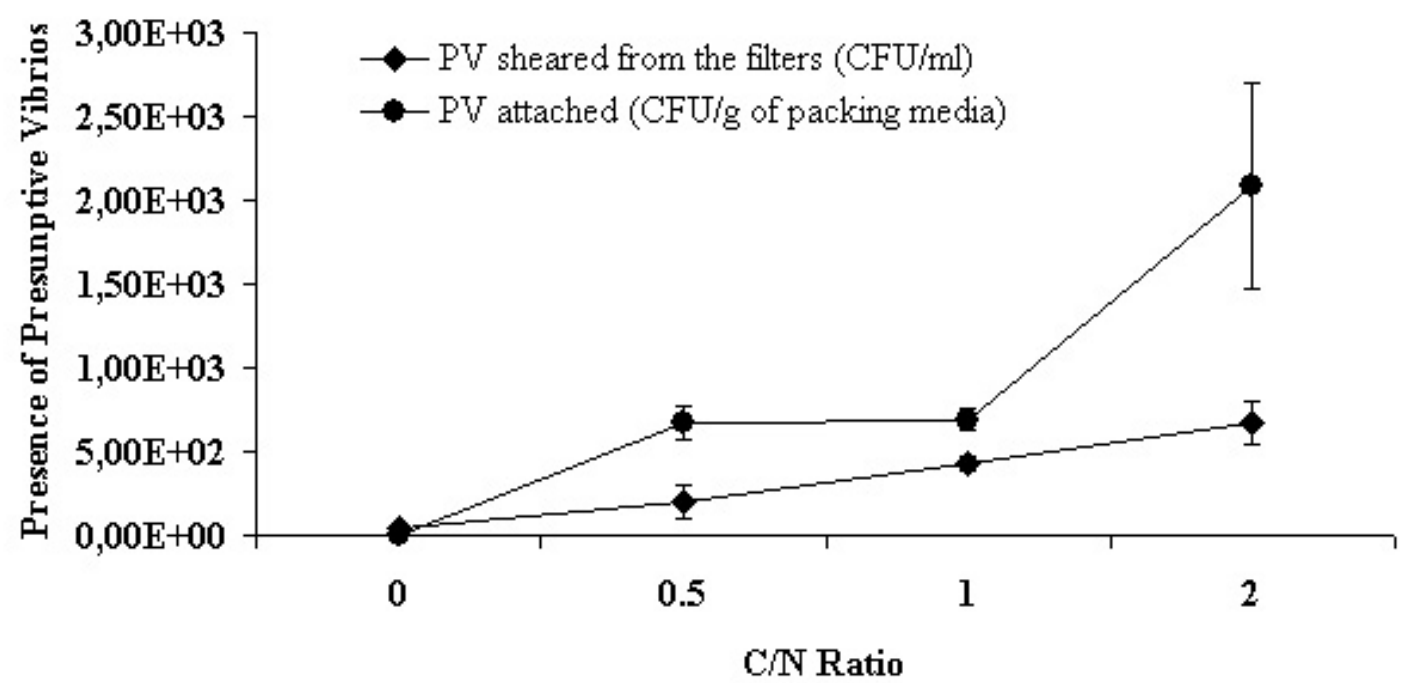

\section{Conclusion}

The approach used here for bacteria monitoring was effective and provided a basis for evaluating changes in bacterial abundance that help to explain changes in biofilter performance associated with increased POM loading. Results from the present study clearly showed a strong relationship between $\mathrm{C} / \mathrm{N}$ ratio and heterotrophic bacterial abundance in biological filters. Moreover, the results shown that there is a linear correlation between the number and type of bacteria fixed on the packing media and sheared from the filter. No differences were detected between the amount of POM entering and exiting the filter even though biofilm growth and bacteria production were positively influenced by the substrate loading. Further analyses should be carried out to investigate the composition of this influent and effluent POM. The results obtained highlight the importance of the control and management of particulate organics in recirculating fish production systems, for example, by better mechanical filtration.

Nitrification efficiency was negatively affected by the increase in the $\mathrm{C} / \mathrm{N}$ ratio, suggesting that the fast growing heterotrophs, found in the outer layers of a biofilm, reduced the availability of oxygen and the diffusion of ammonia to the deeper layers where the slow growing nitrifiers were probably found. In addition, heterotrophic populations produce significant quantities of bacterial biomass, which may contribute to the clogging of a filter and reduce nitrification capacity. On the other hand, the heterotrophic layer could also have a positive effect on nitrification by protecting nitrifiers from detachment and grazing.

Further research on heterotrophic bacteria in biological filters is necessary to acquire the capacity to manage these populations for at least three main reasons: 1) try to reduce the impact of microbial processes that cause a degradation of rearing water (oxygen consumption, secretion of metabolite by-products, etc.); 2) to evaluate and reduce the negative interaction between heterotrophic and autotrophic bacteria; and 3) to exploit the potential benefits of heterotrophs as biocontrol agents (Léonard et al., 2000, 2001; Verschuere et al., 2000). 


\section{Acknowledgement}

This study was conducted with the financial support of the European Research Program ASEFAF (Access to South European Finfish Aquaculture Facilities; Project "C/N Ratio influence on bacterial populations in biological filters in a European sea bass (Dichentrarchus labrax) recycled system) and the Doctoral School "Dottorato di Ricerca in Scienze Ambientali: Ambiente Marino e Risorse" of the University of Messina, Italy.

\section{References}

Bedard, C. and Knowles, R., 1989. Physiology, biochemistry and specific inhibitors of $\mathrm{CH}_{4}, \mathrm{NH}_{4}$ and CO oxidation by methanotrophs and nitrifiers. Microbiol. Rev. 53, 68-84.

Chen, Y.S., Beveridge, M.C.M., Telfer T.C., Roy, W.J., 2003. Nutrient leaching and settling rate characteristics of the faeces of the Atlantic salmon (Salmo salar, L.) and the implications for modeling of solid waste dispersion. J. Appl. Ichthyol. 19, 114-117.

FDZ- Polanco, F., Méndez, E., Uruena, M.A., Villaverde, S., Garcìa, P.A., 2000. Spatial distribution of heterotrophic and nitrifiers in a submerged biofilter for nitrification. Wat. Res. 34, 4081-4089.

Franco-Nava, M., 2003. Origine, devenir et contrôle de la matière particulaire dans les élevages de poisons marins en système recycle. PhD Thesis, Ecole Nationale Supérieure Agronomique de Rennes.

Kirchman, D.L., 1994. The uptake of inorganic nutrients by heterotrophic bacteria. Microb. Ecol. $28,255-271$.

Léonard N., Blancheton J.P., Guiraud J.P., 2000. Populations of heterotrophic bacteria in an experimental recirculating aquaculture system. Aquacult. Eng. 22, 109-120.

Léonard N., Guiraud J.P., Gasset E., Caillères J.P., Blancheton J.P., 2002. Bacteria and nutrients nitrogen and carbon - in a recirculating system for sea bass production. Aquacult. Eng. 26, 111-127.

Mermillond-Blondin F., Fauvet G., Chalamet A., Creuze Des Chatelliers M., 2001. A comparison of two ultrasonic methods for detaching biofilms from natural substrata. Internat. Rev. Hydrobiol. 86, 349-360.

Nogueira R., Melo L. F., Purkhold U., Wuertz S., Wagner M., 2002. Nitrifying and heterotrophic population dynamics in biofilm reactor: effects of hydraulic retention time and presence of organic carbon. Water Res. 36, 469-481.

Ohashi A., Viraj de Silva D.G., Mobarry B., Manem J.A., Stahl D.A., Rittmann B.E., 1995. Influence of substrate $\mathrm{C} / \mathrm{N}$ ratio on the structure of multi-species biofilms consisting of nitrifiers and heterotrophs. Wat. Sci. Tech. 32, 75-84.

Okabe S., Hiratia K., Ozawa Y., Watanabe Y., 2000. Spatial microbial distributions of nitrifiers and heterotrophs in mixed-population biofilms. Biotech. and Bioeng. 50, 24-35.

Porter K.G., Feig Y.S., 1980. The use of DAPI for identifying and counting aquatic microflora. Limnol. Oceanogr. 25, 943-948. 
Russel J.B. and Cook G.M., 1995. Energetic of bacterial growth: balance of anabolic and catabolic reactions. Microbiol. Rev. 59, 48-62.

Strouss M., Kuenen J.G., Jetten M.S.M., 1999. Key physiology of anaerobic ammonium oxidation. Appl. Environ. Microbiol. 65, 3248-3250.

Strouss M., Van Gerven E., Ping Z., Kuenen J.G., Jetten M.S.M., 1997. Ammonium removal from concentrated waste stream with the anaerobic amminium oxidation (anammox) process in different reactors configurations. Wat. Res. 31, 1955-1962.

Tal Y., Watt J.E.M., Schreier S.B., Sowers K.R., Shreier H.J., 2003. Characterization of the microbial community and nitrogen transformation processes associated with moving bed bioreactors in a closed recirculated mariculture system. Aquacult. 215, 187-202.

Treguer P. and La Corre P., 1974. Manual d'analyse des sels nutritifs dans l'eau de mer. Utilisation de l'autoanaliseur II, Technicon ${ }^{\circledR}$, Université de Bretagne Occidentale (Publisher), Brest, France, p. 110 .

Verschuere L., Rombaut G, Sorgeloos P., Verstraete W., 2000. Probiotic bacteria as biological control agents in aquaculture. Microbiol. Mol. Biol. Rev. 64, 655-671.

Zhu S. and Chen S., 1999. An Experimental Study on Nitrification Biofilm Performances Using a Series Reactor System. Aquacult. Eng. 20, 245-259. 